\title{
PENGURANGAN KETIDAKPASTIAN PADA PEKERJA SALON TUNARUNGU DALAM MELAYANI PELANGGAN BARU
}

\author{
Andheka Malestha1, Ratri Kusumaningtyas ${ }^{2}$ \\ 1,2Program Studi Ilmu Komunikasi, Universitas Muhammadiyah Surakarta \\ Jl. A. Yani Tromol Pos 1 Pabelan, Surakarta 57162
}

\begin{abstract}
ABSTRAK
Penelitian ini bertujuan untuk mengetahui bagaimana bentuk ketidakpastian yang dialami oleh pekerja salon tuna rungu sebagai cara mereka mengurangi ketidakpastian dalam berkomunikasi dengan pelanggan baru. Penelitian ini adalah penelitian deskriptif kualitatif, Adapun pengumpulan data menggunakan wawancara mendalam dan observasi terhadap 4 orang pekerja salon tunarungu. Hasil dari penelitian ini menunjukkan bentuk ketidakpastian yang dialami oleh para pekerja salon tunarungu antara lain: 1) Ketidakpastian kognitif, kekhawatiran tentang keterbatasan yang mereka buat sulit mendapatkan informasi yang jelas, tidak bisa memahami keinginan pelanggan, ketakutan akan mendapat prasangka buruk dari pelanggan. 2) Ketidakpastian perilaku adalah ketidakmampuan untuk memperkirakan perilaku pelanggan baru, khawatir akan adanya keluhan jika mereka tidak puas dengan perawatan yang diberikan, khawatir tentang pelanggan yang menawar harga lebih rendah dari yang ditetapkan. Proses pengurangan ketidakpastian yang dialami oleh pekerja salon tunarungu: 1)Proses proaktif, di mana pekerja salon tunarungu berpikir tentang opsi komunikasi yang akan mereka lakukan, menyapa secara langsung, memikirkan untuk berkomunikasi verbal atau tidak. 2) Proses retroaktif, menjelaskan bagaimana berinteraksi dengan pelanggan baru, bagaimana sikap dan perilaku lawan bicara Ketika berinteraksi dengan mereka. Selain itu strategi pengurangan ketidakpastian dilakukan oleh pekerja salon tunarungu. 1) Strategi pasif, dengan melakukan pengamatan sebagai upaya mencari tahu tentang pelanggan baru dan apa yang harus mereka lakukan. 2) Strategi aktif, pekerja salon tunarungu mencari informasi menggunakan orang ketiga untuk membantu atau dengan kata lain bertanya tentang seseorang melalui orang lain. 3) Strategi interaktif, pekerja salon tunarungu berinteraksi secara langsung untuk mengurangi rasa ketidakpastian yang mereka alami.
\end{abstract}

Kata kunci: pengurangan ketidakpastian, tunarungu, komunikasi interpersonal

\begin{abstract}
This research aims to know how the forms of uncertainty experienced by deaf salon workers, as well as how they reduce uncertainty in communicating with new customers. This research is a qualitative descriptive research, such as for the collections of data using indepth interviews and observations of 4 people at the deaf salon workers. The research of this studi show the form of uncertainty experienced by the workers among others: 1) Cognitive uncertainty, worries about the limitations they have made them difficult to get clearinformation, not able to understand customer's wishes, fear will get bad prejudice from customers. 2) Behavior uncertainty is an inability to estimate new customer behavior, worry there will be complaints if you are not satisfied with the treatment provided, worries about a customer bidding a lower price than the one set. The process of reducing uncertainty experienced by deaf salon workers: 1) Proactive process, where the deaf salon workers thinks about the communication options it will do, they great them directly, think of verbal communication and not. 2) Retroactive process, where the deaf workers explained how to interact with new customers, how the attitude and behaviors of the opponent talk about interacting with them.
\end{abstract}


In addition to the uncertainty reduction strategy undertaken by deaf salon workers. 1) Passive strategy, by doing observations as an effort to find out about new customers and what do they have to do. 2) Active strategy, deaf salon workers looking for information using third person help or in other words ask about someone through others. 3) Interactive strategy, deaf salon workers perform interactions directly to reduce the sense of uncertainty they experience.

Keywords: Uncertainty reduction, deaf, interpersonal communication

\section{A. PENDAHULUAN}

Komunikasi merupakan sebuah komponen yang sangat penting untuk keberlangsungan kehidupan manusia. Karena sejatinya manusia adalah mahkluk sosial yang akan selalu membutuhkan orang lain dalam menjalani kehidupan (Morissan, 2018). Umumnya dalam proses komunikasi penyampaian pesan harus dapat diterima secara timbal balik, sehingga komunikasi dapat berjalan layaknya komunikator dan komunikan saling berkomunikasi. Fungsi komunikasi tersebut sebagai penyampaian pesan yang mengisyaratkan bahwa komunikasi itu penting untuk membangun konsep yang ada di diri kita, untuk kelangsungan hidup, dan memupuk hubungan dengan orang lain. (Mulyana, 2010). Dalam komunikasi, manusia juga seringkali berada dalam situasi baru yang penuh ketidakpastian. Ketidakpastian dalam komunikasi dapat terjadi pada siapapun termasuk kaum tunarungu.

Menurut penelitian Wijaya (2017), Hambatan komunikasi yang dialami tunarungu bisa berupa gangguan fisiologis dan gangguan semantik. Gangguan fisiologis terjadi karena seseorang tidak dapat berbicara dan mendengar sehingga komunikasi tidak dapat berjalan secara maksimal. Adapun gangguan semantik disebabkan adanya perbedaan interpretasi atau makna mengenai isi pesan yang disampaikan kedua belah pihak yang saling berkomunikasi. Perbedaan semacam itu dapat dikarenakan adanya penggunaan bahasa maupun istilah yang berbeda sehingga memicu perbedaan penafsiran.

Salah satu hal yang cukup menarik diteliti terkait topik ketidakpastian dalam komunikasi adalah fenomena ketidakpastian pekerja salon tunarungu ketika menghadapi pelanggan baru. Di kampung Turisari Mangkubumen terdapat sebuah usaha salon yang dimiliki oleh penyandang tunarungu. Salon yang dijadikan obyek penelitian ini adalah salon Niniek. Nama tersebut diambil dari nama pemiliknya seorang wanita berusia 53 tahun yang merupakan penyandang tunarungu. Layanan perawatan dibuka setiap hari mulai jam 8 pagi hingga jam 5 sore. Salon Niniek lebih banyak melayani pelanggan wanita, baik remaja, dewasa, maupun orang tua.

Tunarungu sendiri merupakan orang dengan keadaan indera pendengaran yang tidak dapat berfungsi dengan baik. Karakteristik tunarungu misalnya seperti kurangnya respon saat dipanggil jarak dekat maupun jauh. Orang penyandang disabilitas khususnya tunarungu memiliki keterbatasan dalam berkomunikasi. Penyebab tunarungu diantaranya adalah faktor keturunan, virus rubella, radang selaput otak, ketidaksesuaian darah antara anak dengan ibu yang mengandungnya, toxaminia, pemakaian antibiotik overdosis, infeksi, otitis media kronis, dan infeksi pada alat-alat pernapasan (Haenudin, 2013).

Adapun pengertian lain dari tunarungu adalah seseorang yang tidak atau kurang mampu untuk mendengar suara. Pada tunarungu ini terdapat dua kategori yang menjadi perbedaannya yaitu tuli dan kurang mendengar. Tuli adalah seseorang yang indera pendengarannya mengalami kerusakan pada taraf berat sehingga mengakibatkan pendengarannya tidak dapat berfungsi kembali. Sedangkan kurang mendengar adalah seseorang yang mengalami kerusakan dalam hal pendengaran, akan tetapi masih dapat berfungsi untuk mendengarkan suara orang lain dengan baik tanpa menggunakan alat 
bantu pendengaran yang dipasang pada telinga (Haenudin, 2013).

Hal yang ingin dikaji dalam penelitian ini yakni ketidakpastian yang dialami pekerja salon tunarungu saat berhadapan dengan pelanggan baru yang merupakan pendengar normal. Ketidakpastian yang dialami penyandang disabilitas khususnya tunarungu seringkali muncul karena keterbatasan informasi yang didapatkan. Umumnya proses penyampaian pesan harus dapat dipahami oleh komunikator dan komunikan, sedangkan dalam hal ini terdapat hambatan komunikasi. Keterbatasan informasi yang didapatkan tunarungu mengakibatkan mereka cenderung memilih diam dan pasif. Dalam proses komunikasi antara tunarungu dan pelanggan baru melibatkan komunikasi secara verbal maupun non-verbal. Proses penyampaian pesan oleh pelanggan baru yang terlalu cepat membuat penyandang tunarungu kurang mampu menyesuaikan percakapan. Baik dalam memberikan penjelasan, memprediksi sesuatu, perasaan, nilai dan sikap (Primasari, 2014).

Adapun penelitian terdahulu yang menjadi referensi peneliti dalam menulis penelitian ini adalah penelitian Alysha Paxia Susilo (2017) yang berjudul Memahami Komunikasi Penyesuaian Diri Anak Tunarungu Di Sekolah Inklusi. Penelitian ini membahas tentang upaya pengurangan ketidakpastian oleh penyandang tunarungu dalam menjalin hubungan pertemanan yang ada di lingkungan sekolah (Susilo, 2017).

Perbedaan dalam penelitian ini adalah fokus dalam penelitian tersebut, yakni komunikasi yang dilakukan dalam ruang lingkup sekolah dan terjadi pada siswa sekolah. Sedangkan yang akan menjadi kajian peneliti adalah komunikasi pada pekerja salon. Adapun persamaan dalam penelitian ini berfokus dari adanya pengurangan ketidakpastian yang dialami. Alasan peneliti memilih komunikasi pada pekerja salon tunarungu karena dalam penelitian ini masih jarang diteliti dan satusatunya yang ada di wilayah Mangkubumen.
Sehingga akan memberikan wawasan mengenai komunikasi tunarungu khususnya tentang pengurangan ketidakpastian yang kerap dihadapi di lingkungan masyarakat.

\section{B. TINJAUAN PUSTAKA}

Penelitian ini menggunakan Teori Pengurangan Ketidakpastian (Uncertainty Reduction Theory) yang dicetuskan oleh Charles Berger dan Richard Calabrese di tahun 1975 bertujuan untuk menjelaskan bagaimana komunikasi digunakan untuk mengurangi ketidakpastian di antara orang asing yang terlibat perbincangan satu sama lain untuk pertama kali. Charles Berger dan Richard Calabrese yakin bahwa ketika orang asing pertama kali bertemu, utamanya mereka tertarik untuk meningkatkan prediktabilitas dalam usaha untuk memahami pengalaman komunikasi di antara mereka (West \& Turner, 2008). Ada beberapa asumsi Teori Pengurangan Ketidakpastian yang membingkai teori ini misalnya, orang mengalami ketidakpastian dalam latar interpersonal, ketidakpastian ini adalah keadaan yang tidak mengenakkan yang dapat menimbulkan stres secara kognitif, ketika orang asing bertemu, perhatian utama dari mereka adalah untuk mengurangi ketidakpastian mereka atau justru meningkatkan kredibilitas, komunikasi interpersonal adalah alat yang utama untuk mengurangi ketidakpastian, kuantitas dan sifat informasi yang dibagi oleh orang akan berubah seiring berjalannya waktu (West \& Turner, 2008).

West dan Turner (2008) menjelaskan bahwa teori pengurangan ketidakpastian juga memiliki asumsi-asumsi dasar di antaranya sebagai berikut, a) Saat berkomunikasi interpersonal dengan orang yang tidak dikenalnya, seseorang mengalami ketidakpastian, b) Ketidakpastian dapat memicu tekanan kognitif, karena ketidakpastian merupakan suatu situasi yang tidak disukai, c) Ketika dua orang yang saling tidak mengenal bertemu dan harus terlibat di dalam sebuah percakapan, maka mereka akan memulai sebuah prediksi-prediksinya atau perkiraan 
mengenai informasi dari diri lawan bicaranya, d) Komunikasi interpersonal merupakan sebuah situasi yang dapat berkembang pesat melalui tahap-tahap. Pada tahap awal individu memulai interaksi, tahap kedua yaitu mengenai tahap personal di mana ungkapan individu atau pribadi mulai diungkapkan, dan tahap ketiga yaitu ketika seseorang sebagai penerima akan memutuskan untuk melanjutkan hubungan atau justru memutuskan hubungannya, e) Alat utama untuk mengurangi tingkatan ketidakpastian yaitu komunikasi interpersonal, f) Elemen penting dalam perkembangan hubungan interpersonal adalah jumlah dan sifat informasi yang selalu berubah serta dapat bertambah dan interaksi awal dalam hubungan komunikasi juga merupakan elemen yang sangat penting, g) Kita dapat menduga pada perilaku seseorang dengan orang-orang yang memiliki karakter sama dan juga gaya hidup yang sama (West \& Turner, 2008).

Teori Pengurangan Ketidakpastian menyatakan bahwa tidak peduli pada seberapa dekat antara seorang individu atau pribadi yang satu dengan individu lain, hubungan mereka pasti di mulai dengan rasa asing dan penuh rasa ketidakpastian. Hal yang sama juga terjadi pada seseorang ketika berjumpa dengan orang lain yang normal, komunikasi interpersonal merupakan suatu bentuk komunikasi yang termasuk paling kerap digunakan dalam berinteraksi pasif, aktif, dan interaktif. Cara dan strategi pengurangan ketidakpastian yang kerap selalu dilakukan oleh mereka di antaranya sebagai berikut, a) Strategi pasif (passive strategies) yang di mana seseorang mengambil peranan pengamat yang tidak mengganggu terhadap orang lainnya, b) Strategi aktif (active strategies) yang merupakan usaha untuk selalu aktif bertanya kepada orang lain tentang seseorang untuk mendapatkan sebuah informasi, c) Strategi interaktif (interactive strategies) yang merupakan suatu kegiatan pengungkapan informasi pribadi atau diri dan transparan dengan orang lain, serta mengharapkan orang lain juga melakukan perihal yang sama. Ada dua proses pada pengurangan ketidakpastian yaitu proaktif dan retroaktif. Proaktif merupakan suatu proses pengurangan ketidakpastian yang berada pada tahap ketika seseorang berpikir sebelum melakukan komunikasi dengan orang lain. Menurut West \& Turner (2008), retroaktif merupakan suatu proses di saat seseorang menjelaskan perilaku orang lain ketika bertemu.

Komunikasi dianggap sebagai suatu peran penting dalam proses pengurangan ketidakpastian dalam diri seseorang (Gibbs et. al., 2011). Hal yang harus dilakukan seseorang dalam mengurangi rasa ketidakpastian antara lain sebagai berikut, a) Komunikasi verbal yakni menunjukkan bahwa semakin banyak komunikasi verbal dilakukan maka akan mengurangi rasa ketidakpastian, b) Ekspresi afiliasi nonverbal yakni suatu faktor dalam proses pengurangan ketidakpastian berupa kontak mata, anggukan kepala, gesture, dan ekspresi non-verbal yang lain yang artinya semakin banyak komunikasi non-verbal ini diekspresikan, maka ketidakpastiannya akan dapat berkurang, c) Pencarian informasi yakni ketidakpastian yang tinggi meningkatkan kegiatan pencarian informasi, d) Kedekatan yakni tingkat kedekatan pada suatu isi informasi dalam pembicaraan yang dilakukan akan meningkat apabila ketidakpastiannya rendah, e) Timbal balik yakni pemberian dan penerimaan suatu pesan yang sama merupakan bentuk rendahnya ketidakpastian akan seseorang, f) Kesamaan yakni kesamaan yang sudah ada antar penerima yang melakukan interaksi akan mengurangi ketidakpastian, begitupun sebaliknya karena ketidaksamaan yang meningkat akan meningkatkan penjelasan alternatif pada perilaku seseorang pula, g) Kesukaan yakni semakin tinggi ketidakpastian yang ada dalam benak seseorang akan menurunkan tingkat kesukaan akan orang lain (West \& Turner, 2008).

Penggunaan teori pengurangan ketidakpastian dapat menjelaskan bentukbentuk ketidakpastian dan proses maupun strategi yang dilakukan pekerja salon dalam mengurangi ketidakpastian.. 


\section{METODE}

Penelitian ini merupakan penelitian kualitatif dengan menggunakan jenis penelitian deskriptif. Secara umum penelitian deskriptif merupakan metode riset yang memiliki tujuan untuk menjelaskan secara spesifik pada suatu peristiwa dengan cara mendeskripsikan atau menggambarkan penelitian (Morissan, 2018).

Adapun teknik pemilihan informan dalam penelitian ini menggunakan teknik purposive sampling yang melibatkan sejumlah 4 orang yakni NN berusia 53 tahun, YT berusia 48 tahun, SR berusia 51 tahun, dan KM berusia 45 tahun, selaku pekerja salon tunarungu. Teknik purposive sampling merupakan teknik untuk menentukan informan pada penelitian dengan beberapa pertimbangan tertentu yang bertujuan agar data yang dipilih lebih representatif (Sugiyono, 2017). Kriteria informan dalam penelitian ini yaitu pekerja salon tunarungu di salon Niniek.

Teknik pengumpulan data yang digunakan oleh peneliti yaitu menggunakan dua cara yang sesuai dengan kebutuhan peneliti. Pertama, peneliti menggunakan wawancara mendalam. Wawancara mendalam adalah suatu proses yang memberikan pertanyaan kepada informan yang dilakukan langsung untuk mengetahui secara mendalam tentang berbagai hal yang masih belum terungkap oleh informan. (Sugiyono, 2017) Wawancara ini digunakan sebagai teknik pengumpulan data oleh peneliti untuk menemukan suatu masalah yang akan di teliti. Wawancara pada penelitian ini dilakukan dengan pekerja salon tunarungu untuk diambil data mengenai ketidakpastian yang dialami dan proses sekaligus strategi pengurangan ketidakpastian yang dilakukan pekerja salon tunarungu. Kedua, peneliti menggunakan observasi. Observasi adalah proses pada penelitian yang berarti mengamati dalam situasi dan kondisi (Sugiyono, 2017) Bagi peneliti observasi dilakukan dengan mengamati kegiatan pekerja salon tunarungu.
Teknik analisis data dalam penelitian ini menggunakan teknik analisis data interaktif. Teknik analisis data merupakan menganalisis data melalui cara mendeskripsikan atau menggambarkan dari data yang sudah terkumpul sebagaimana adanya tanpa bermaksud membuat suatu kesimpulan (Sugiyono, 2017). Sedangkan teknik analisis data interaktif adalah proses mencari dan menyusun serta menganalisis data yang diperoleh dari hasil wawancara secara sistematis sehingga mudah dipahami dan tentunya dapat diinformasikan kepada orang lain (Miles et al., 2014).

Teknis analisis data Miles dan Huberman berupa reduksi data, penyajian data, dan penarikan kesimpulan di mana peneliti melakukan perbandingan data kemudian memilih data yang dianggap dapat dijadikan data pasti dalam penelitian ini.

Validitas data yang digunakan dalam penelitian ini menggunakan teknik triangulasi sumber data yang bersifat menggabungkan berbagai teknik pengumpulan data yang diperoleh yakni wawancara dan observasi. Triangulasi diartikan sebagai pengecekan data dari berbagai sumber dengan melalui berbagai cara dan berbagai waktu (Sugiyono, 2017). Triangulasi data merupakan teknik untuk menguji validitas keabsahan dari hasil penelitian dengan menggunakan informasi di luar data untuk dibandingkan dengan data yang diperoleh di lapangan (Krisyantono, 2006). Triangulasi sumber merupakan cara dimana peneliti menggali kebenaran data dengan membandingkan data dari informan satu dengan yang lain.

\section{TEMUAN}

Berdasarkan penelitian yang telah dilakukan, didapatkan hasil bahwa pekerja salon tunarungu yang harus menghadapi pelanggan baru, mengalami berbagai ketidakpastian. Oleh karena itu mereka mengurangi rasa ketidakpastian dalam dirinya melalui strategi tertentu pada proses yang mereka jalani sesuai dengan kondisi mereka masing-masing. Berikut ini adalah hasil penelitian yang peneliti peroleh di 
Salon Niniek melalui proses wawancara kepada informan 1 adalah Ibu Niniek, informan 2 adalah lbu Yatik, informan 3 adalah Ibu Sri, dan informan 4 adalah Ibu Kamto yang merupakan pekerja salon tunarungu yang ada disana.

\section{Ketidakpastian yang Dialami Pekerja Salon}

Ketika pekerja salon tunarungu bertemu dan pelanggan baru, mereka mengalami ketidakpastian. Ketidakpastian yang dialami oleh pekerja salon tunarungu dilatarbelakangi oleh keterbatasan informasi yang dimilikinya.

Informan 1:

"Ya, iya dong mas. Kadang pas orang datang itu melihat saya, pas begitu orangnya ngomong la ngomonge cepet banget. Kan kalo pelan-pelan saya paham, ngerti, mau ngapa kedatangan orange ke sini". (Informan 1, 06 Januari 2020)

Informan 2:

"Hahaha. lya, sebenarnya begitu, tapi karena kondisi saya begini. Kan yang pasti saya gak ada apa-apa sama semua. Sama orang baru, kampung, tetangga-tetangga, juga mas. Punya prasangka aneh, buruk ke pelanggan dan juga sebaliknya, yang saya takuti kalo enggak jadi pelanggan tetap. Pikiran buruk saya yang lain itu kalo sampai akhirnya pelanggan bercerita yang di luar perbincangan saya. Seperti menjelekkan saya diluar". (Informan 2, 06 Januari 2020)

Ketidakpastian yang dialami pekerja salon ini terjadi karena adanya kekurangan danketerbatasanyang dimilikiolehinforman. Informan 1 khawatir karena keterbatasan yang mereka miliki membuat mereka kesulitan untuk mendapatkan informasi yang jelas. Apalagi ketika pelanggan baru berbicara dengan cepat dan kurang dapat mereka pahami. Informan 1 merasa khawatir apabila tidak mampu memahami keinginan pelanggan. Sedangkan informan 2 khawatir kekurangan yang mereka miliki akan membuat pelanggan berpikiran aneh mengenai mereka dan membuat mereka segan untuk menjadi pelanggan di salon tersebut. Informan 3 dan 4 juga menjelaskan hal yang sama dengan informan 1 dan 2, dimana mereka khawatir keterbatasan yang mereka miliki akan menghambat penyampaian dan penerimaan informasi sehingga mereka tidak memahami maksud dan keinginan pelanggan, serta khawatir pelanggan berprasangka buruk. Ketidakpastian kognitif tersebut membuat para pekerja salon cenderung bersifat pasif dan mengikuti instruksi pelanggan baru pada saat melakukan perawatan secara berlangsung.

Informan di Salon Niniek memiliki perkiraan mengenai perilaku pelanggan yang ditemui di sana, namun beberapa kali ditemui bahwa kenyataan yang dialami berbeda, seperti yang dinyatakan informan 2 sebagai berikut:

Informan 2:

"Kesel apa marah karena enggak merasa puas kepada saya pas melakukan treatment. lya, itu mas yang kadang saya merasa was-was gitu mas. Sama nawar harga yang sudah saya tentukan mas. Ada juga loh yang langsung ngasih paksa uang gak seberapa". (Informan 2, 06 Januari 2020)

Ketidakpastian perilaku yang dialami informan 2 terjadi karena ia tidak mampu memperkirakan apa yang akan dilakukan oleh pelanggan baru. Ketika pertama kali bertemu pelanggan baru, informan diberikan instruksi terkait treatment yang akan dilakukan. Informan 2 merasa waswas dan khawatir bahwa pelanggan akan memberikan complain apabila tidak puas dengan treatment yang diberikan, selain itu terkadang terjadi hal yang diluar dugaan informan contohnya ketika pelanggan masih menawar harga yang sudah ditentukan. Hal ini membuat mereka berpikir bahwa pelanggan baru cenderung akan berperilaku tidak baik terhadap mereka. Informan 1, informan 3, dan informan 4 juga menjelaskan hal yang serupa bahwa mereka merasa khawatir dengan perilaku pelanggan baru yang tidak terduga. 


\section{Proses Pengurangan Ketidakpastian}

Melalui wawancara yang peneliti lakukan di Salon Niniek, ada beberapa proses pengurangan ketidakpastian yang dialami pekerja salon tunarungu.

Informan 1:

"Saya mikir untuk nyoba nyapa langsung orangnya Mas. Jadi kalau pelanggan udah mendengar suara saya biasanya orang mulai pelan cara ngomongnya. Nggak terlalu cepat. Jadi saya jadi tahu apa yang diinginkan ketika disini". (Informan 1, 16 Januari 2020)

Dalam hal ini informan 1 memikirkan pilihan komunikasi dengan menyapa secara langsung untuk kemudian menunggu respon dari pelanggan. Informan 1 memperkirakan bahwa ketika dirinya sudah menyapa pelanggan, selanjutnya dapat saling menyesuaikan cara berkomunikasi mereka. Informan 2, informan 3, dan informan 4 juga sejalan dengan pernyataan informan 1. Selain itu pekerja salon tunarungu cenderung akan memikirkan terlebih dahulu kalimat verbal maupun non verbal, tindakan apa yang akan mereka tunjukkan kepada pelanggan baru.

Hal lain mengenai proses pengurangan ketidakpastian juga diungkapkan oleh informan berikut:

Informan 1:

"lya, dilakukan berulang mas.

Maksudnya begini, pelanggan yang datang bersamaan dengan temennya itu justru sudah tau lebih dulu kondisi saya. Manfaat dia cerita ini agar mudah dimengerti di waktu saya ngobrol. Ada masukan yang diberikan untuk saya seperti di depan pintu harusnya dikasih info kalo disini semua tunarungu. Jadi orang bisa sudah sadar dan tau langsung". (Informan 1, 16 Januari 2020)

Pekerja salon tunarungu menjelaskan bagaimana respon lawan bicara atau pelanggan baru, bagaimana mereka berperilaku setelah berkomunikasi dengan dirinya. Menurut informan 1 penyampaian informasi antara dirinya dengan pelanggan baru kadang dilakukan secara berulang dan kadang melibatkan orang ketiga yang lebih paham kondisi informan sehingga penyampaian informasi dapat berlangsung dengan baik. Hal ini juga diikuti oleh informan 2, informan 3, dan informan 4 bahwa setelah berkomunikasi dengan pelanggan baru mereka memiliki gambaran apa yang harus dilakukan selanjutnya.

Terkait dengan proses pengurangan ketidakpastian yang dilakukan oleh pekerja tuna rungu, para informan mengungkapkan bahwa ada beberapa hal yang mengiringi proses tersebut:

Informan 1:

"lya, pakai juga mas. Seperti mas lihat sekarang ini tapi pelafalan yang kurang dimengerti. Maksudnya hanya kalimat belakang saja yang membuat orang tahu". (Informan 1, 16 Januari 2020)

Informan 3:

"Sederhana aja mas. Bertanya soal penambahan di dalam perawatannya gunakan merek apa. Apa yang ada disini apakah sudah ada apa belum gitu". (Informan 3, 16 Januari 2020)

Pendapat informan 1 menunjukkan bahwa pada awal interaksinya penyampaian kata dan kalimat secara verbal merupakan sebuah proses yang juga membantu mengurangi ketidakpastian. Meskipun merasa kesulitan dalam pelafalan namun komunikasi secara verbal tetap digunakan oleh pekerja tuna rungu mengingat yang dihadapi adalah orang-orang yang memang terbiasa menggunakan komunikasi verbal. Sedangkan Informan 3 menjelaskan bahwa ketika seseorang membatasi diri dengan tidak banyak berbicara, maka lawan bicara akan semakin mengalami ketidakpastian, menurutnya lebih baik mereka mencoba untuk berkomunikasi dengan pelanggan meskipun harus dengan penyesuaian daripada tidak menggunakan komunikasi verbal sama sekali. Informan 2 dan informan 4 bersepakat tentang pernyataan tersebut.

Selain itu, pekerja salon mengharapkan pelanggan baru juga menggunakan komunikasi non-verbal agar pesan yang disampaikan dapat mereka terima. 


\section{Informan 2:}

"kalo sama pelanggan baru ya pas bicara mata sejajar dengan fokus kepada pelanggan, menggerakkan kedua tangan untuk menyambut kedatangan, ekspresinya ramah, kadang juga pake gerakan tangan untuk mempermudah, untuk bicara langsung biasanya saya sedikit mendekat untuk mendengar instruksinya, dan biar bisa lihat gerak bibirnya". (Informan 2, 16 Januari 2020)

Informan 2 menunjukkan bahwa komunikasi non verbal berperan sangat penting mengingat mereka memiliki keterbatasan dalam memahami komunikasi verbal. Untuk berkomunikasi dengan pelanggan normal, mereka menggunakan pengaturan jarak dengan mendekatkan diri ketika berbicara, pandangan mata yang fokus ke pelanggan, ekspresi ramah, hingga gerakan tangan untuk memudahkan penyampaian pesan. Informan pada awalnya merasakan bahwa pelanggan baru menunjukkan ekspresi yang tidak terlalu bervariasi ketika awal interaksi dan tidak memberikan informasi mengenai jasa perawatannya, informan pun berusaha untuk mendekati dan menunjukkan ekspresi non verbal dengan lebih aktif. Informan 1, informan 3, dan informan 4 menyiratkan hal yang serupa dengan pernyataan informan 2.

Di saat pencarian informasi mulai tidak dilakukan lagi, maka tingkat ketidakpastian yang dialami juga mengalami penurunan. Pekerja salon tunarungu juga melalui hal ini ketika berada dalam masa-masa awal berada di salon dan tengah mengalami proses pengurangan ketidakpastian dalam pekerjaan.

Informan 3:

"Biasanya saya tanya-tanya ke teman lain tentang treatment apa yang umumnya disukai pelanggan. Treatmentnya yang sudah sering pelanggan pilih itu seperti potong rambut, nyemir rambut, dan juga hanya keramas saja. Setelah semua sudah dilakukan saya berpesan untuk mengajak kembali lagi bersama temen". (Informan 3, 16 Januari 2020)
Pernyataan informan 3 menunjukkan bahwa ia membutuhkan informasi akan treatment yang kerap dipilih pelanggan baru, di mana informasi tersebut harus di cari dan didapatkan untuk mengurangi ketidakpastian yang akan menjadi tergantung pikirannya ketika ia masukkan ke dalam perawatan dan kecantikan. Informan 3 menjelaskan bahwa ia mencari informasi dengan bertanya kepada pemilik salon untuk mencari informasi mengenai kelengkapan treatment yang ada disini. Sedangkan informan 1, informan 2, dan informan 4 mengatakan tidak mencari informasi sebelum masuk ke salon melainkan mencari informasi dengan observasi sendiri ketika sudah ada di salon.

Kedekatan juga menjadi hal penting dalam pengurangan ketidakpastian, hal ini seperti yang diungkapkan oleh informan berikut:

Informan 2:

"Mengajaknya ngobrol tentang penggunaan treatment yang sering dipilih, merek yang di suka. Dengan kedekatan itu membuat saya semakin dekat dan bisa mengurangi rasa ketidakpastian saya kepada pelanggan". (Informan 2, 16 Januari 2020)

Informan 2 menyatakan bahwa ia telah memiliki kedekatan dengan salah seorang pelanggan baru. Pembicaraan yang intensitasnya lebih banyak menunjukkan bahwa ada kedekatan isi pesan yang dimiliki antar pekerja salon tunarungu, sehingga ketidakpastian di dalam dirinya berkurang. Informan 1, informan 3, dan informan 4 tidak memberikan pernyataan ketika wawancara dilakukan mengenai hal yang berkaitan dengan intimasi ini.

Adanya timbal balik juga berpengaruh dalam proses pengurangan ketidakpastian: Informan 2:

"lya, gunanya itu untuk menarik pelanggan agar kembali lagi. Biasanya saya mulai dengan memperhatikan orang dengan yang saya liat dulu. Misal rambut temen udah panjang gitu saya langsung aja bilang mau potong, rambut itu udah panjang. Temen 
langsung datang besoknya. Begitu terus cara yang saya lakukan mas". (Informan 2, 16 Januari 2020)

Pekerja salon tunarungu sebagai informan menjelaskan bahwa ketika mereka berada pada awal-awal interaksi, mereka akan melakukan banyak interaksi yang sifatnya bertanya dan menjawab. Hal ini berguna bagi pencarian dan pengumpulan informasi akan seseorang yang memiliki kemungkinan besar akan kerap berada di sekitar mereka. Penting bagi setiap pekerja salon tunarungu untuk bisa memahami seseorang yang baru bertemu dengannya yang sedang melakukan perawatan. Tidak jarang mereka memerlukan bantuan orang lain sebagai perantara untuk membantu menyampaikan informasi. Informan 1, informan 3, dan informan 4 juga menjelaskan pertanyaan yang mereka sampaikan variatif ketika mereka berada pada awal-awal berkomunikasi. Selanjutnya ketika informan mengalami pengurangan ketidakpastian, interaksi mereka berubah menjadi saling bertegur sapa dan interaksi ringan, bukan semata-mata kegiatan timbal balik untuk mengumpulkan informasi lagi.

Peneliti mendapatkan pernyataanpertanyaan seorang informan dalam proses wawancara yang menunjukkan faktor kesamaan sebagai berikut.

Informan 3:

"lya, misale kayak merek yang disini itu kebetulan sesuai dengan pilihan mereka. Itu udah membuat saya senang dan mengurangi ketidakpastian saya kepada pelanggan". (Informan 3, 16 Januari 2020)

Informan 4:

"Saling menjaga perawatan tubuh, sama mengerti tentang perawatan, saling suka merek yang sama". (Informan 4, 16 Januari 2020)

Pernyataan informan 3 dan 4 menunjukkan bahwa kesamaan yang banyak akan pelanggan baru dengan pekerja salon membuat interaksi dan hubungan yang mereka lakukan terasa lebih nyaman. Dalam hal ini inforrman 3 dan 4 memiliki kesamaan mngenai selera, dimana mereka menyukai merek produk perawatan yang sama.

Faktor lain yang penting dalam proses pengurangan ketidakpastian, yaitu faktor kesukaan.

Informan 1:

"Biasanya ya sukanya kalo orang yang ramah dan tau sopan santun, banyak interaksi ketika melakukan treatment, bersuara halus tanpa kasar, intonasi nada yang datar tidak keras, dan yang membayar sesuai harga". (Informan 1, 16 Januari 2020)

Pernyataan informan 1 menunjukkan hal-hal yang memicu kesukaan pada pelanggan baru diantaranya sikap ramah, sopan santun, sikap mereka yang mau berinteraksi selama treatment, berbicara dengan halus dan bersedia membayar sebagaimana harga yang ditetapkan. Pekerja salon tunarungu di Salon Niniek dalam melakukan interaksi berharap bahwa mereka akan memiliki kesan dan penilaian yang baik agar dapat melanjutkan interaksi dan membangun hubungan yang lebih intensif dan dekat. Ketika mereka mengalami suatu permasalahan yang menimbulkan ketidaksukaan mereka akan cenderung menutup diri.. Informan 2, informan 3, dan informan 4 juga mengungkapkan hal yang sama.

\section{Strategi Pengurangan Ketidakpastian}

Ada beberapa hal yang diakukan oleh pekerja salon tunarungu dalam mengurangi ketidakpastian yang mereka alami.

Informan 2:

"lya begitu mas, hanya yang tahu-tahu aja awal mulanya. Biasanya dari temen ke temen gitu udah banyak yang ke sini. Mulai dari potong rambut, cat warna rambut, creambath, facial, udah. ya saya ngamati dulu awalnya, sikap pelanggan baru itu gimana". (Informan 1, 16 Januari 2020)

Pendapat informan 2 menjelaskan bahwa mereka melakukan pengamatan sebagai upaya untuk mengurangi ketidakpastian dalam lingkungan pekerjaan. 
Demikian juga dengan informan 1, informan 3, dan informan 4.

Selain melakukan pengamatan, pekerja salon tunarungu juga mencari informasi dengan menggunakan bantuan orang ketiga atau dengan kata lain menanyakan mengenai seseorang melalui orang lain. Seperti pernyataan yang disampaikan oleh informan 2 sebagai berikut,

\section{Informan 2:}

"lya mas, awalnya cari yang terdekat buat dijadikan perantara mas. Sebelumnya kita sempet kenalan dulu. Baru pas itu saya nanya ke warga lah buat nanya ini nanya itu tentang orange tadi gimana to buat mengecek kurang lebihnya". (Informan 2, 16 Januari 2020)

Strategi ini memungkinkan pekerja salon tunarungu melakukan riset atau pencarian informasi tanpa ia harus mengambil risiko malu atau pun ragu seperti ketika seseorang berjumpa langsung dan berbicara dengan orang asing atau orang yang belum ia kenal. Strategi aktif memang digunakan oleh informan 1, informan 3, dan informan 4 yang ada di Turisari Mangkubumen, yakni menggunakan bantuan pihak ketiga untuk mencari tahu informasi mengenai pelanggan baru.

Kehadiran dirisecara nyata dan langsung membuat pekerja salon tunarungu mampu merasa bahwa seseorang akan lebih cepat memahami satu sama lain.

Informan 1:

"lya mas, iya itu berguna untuk saya. Penambahan daftar treatment yang sekarang ini lagi banyak di cari itu apa saja. Nanya langsung ke pelanggan baru yang habis treatment juga banyak manfaatnya untuk penambahan saran dan masukan bagi saya ke depan. Dengan begitu saya bisa lebih belajar kembali dan memperbaiki mana yang harus ditambahkan". (Informan 1, 16 Januari 2020)

Pekerja salon tunarungu melakukan interaksi secara langsung untuk mengurangi rasa ketidakpastian yang mereka alami. $\mathrm{Hal}$ ini diperkuat oleh pendapat informan sekunder yang merupakan informan 1 bahwa biasanya yang dilakukan oleh informan 1 adalah mendatangi dan berkomunikasi secara langsung. Hal serupa juga dilakukan oleh informan lainnya.

\section{E. BAHASAN}

Ketidakpastian yang dialami pekerja salon ini terjadi karena adanya kekurangan dan keterbatasan yang dimiliki oleh informan. Ketika tunarungu dan pendengar normal bertemu, komunikasi menjadi hal yang lebih menantang. Kesulitan ini umumnya dianggap berasal dari tunarungu yang tidak dapat mendengar dan berbicara dengan baik dan karena itu tidak dapat berkomunikasi dengan cara normal (Young, 2017). Sedangkan dalam teori pengurangan teori pengurangan ketidakpastian ada beberapa hal yang dapat meningkatkan ataupun menurunkan ketidakpastian seseorang akan suatu hal dalam proses komunikasi, diantaranya gangguan atau noise. Para ahli memandang bahwa gangguang fisik yang secara langsung menyerang fisik seseorang seperti tunarungu, dapat mengganggu kecermatan pesan yang disampaikan (West \& Turner, 2008)

Beberapa informan khawatir karena keterbatasan yang mereka miliki membuat mereka kesulitan untuk mendapatkan informasi yang jelas. Apalagi ketika pelanggan baru berbicara dengan cepat dan kurang dapat mereka pahami. Mereka merasa khawatir apabila tidak mampu memahami keinginan pelanggan, khawatir kekurangan yang mereka miliki akan membuat pelanggan berpikiran aneh mengenai mereka dan membuat mereka segan untuk menjadi pelanggan di salon tersebut. Mereka khawatir keterbatasan yang mereka miliki akan menghambat penyampaian dan penerimaan informasi sehingga mereka tidak memahami maksud dan keinginan pelanggan, serta khawatir pelanggan berprasangka buruk. Jenis ketidakpastian tersebut merupakan jenis ketidakpastian kognitifyang merujuk kepada tingkat ketidakpastian yang dihubungkan 
dengan keyakinan dan sikap di mana pekerja salon tunarungu tidak yakin dengan sikap orang lain terhadapnya saat kali pertama bertemu. Ketidakpastian kognitif tersebut membuat para pekerja salon cenderung bersifat pasif dan mengikuti instruksi pelanggan baru pada saat melakukan perawatan secara berlangsung. Seperti penjelasan yang disebutkan oleh Berger, Ketika seseorang berada di dalam fase awal pertemuan, seseorang akan merasa berada dalam situasi yang begitu dibatasi oleh nilai dan norma sehingga jarang untuk bisa melakukan komunikasi secara verbal atau bisa di katakan interaksi sangatlah minim (West \& Turner, 2008).

Ketidakpastian yang dialami terjadi karena kekurangan dan keterbatasan informasi yang dimiliki oleh masing-masing informan (Zuhriah, 2019).

Ada jenis ketidakpastian yang lain yang dialami pekerja salon Selain ketidakpastian kognitif, ada data yang peneliti peroleh dari lapangan yang menunjukkan adanya ketidakpastian perilaku (behavioral uncertainty)yang berkaitan denganseberapa jauh seseorang dapat memperkirakan perilaku orang lain pada situasi tertentu (Febriani, 2015). Ketidakpastian perilaku yang dialami informan 2 terjadi karena ia tidak mampu memperkirakan apa yang akan dilakukan oleh pelanggan baru. Ketika pertama kali bertemu pelanggan baru, informan diberikan instruksi terkait treatment yang akan dilakukan. Merasa was-was dan khawatir bahwa pelanggan akan memberikan complain apabila tidak puas dengan treatment yang diberikan. Selain itu kadang terjadi hal yang diluar dugaan informan, contohnya ketika pelanggan masih menawar harga yang sudah ditentukan. Hal ini membuat mereka berpikir bahwa pelanggan baru cenderung akan berperilaku tidak baik terhadap mereka. Informan juga merasa khawatir dengan perilaku pelanggan baru yang tidak terduga. Hal ini juga terkait dengan perkiraan-perkiraan mengenai apa yang seharusnya mereka lakukan agar pelanggan menerima mereka dengan baik.
Hal ini sejalan dengan penelitian Primasari (2014) dimana ketidakpastian perilaku juga terkait bagaimana seseorang harus memperkirakan tindakan dan perilaku di lingkungan baru agar diterima orang lain.

Adapun proses pengurangan ketidakpastian yang dialami informan, menunjukkan adaya dua proses dari pengurangan ketidakpastian. Ada pun dua proses tersebut adalah proses proaktif (proactive process) dan proses retroaktif (retroactive process). Seperti pendapat Berger (West \& Turner, 2008). proses proaktif terjadi ketika seseorang memikirkan tentang pilihan komunikasi yang akan dilakukan. Di antaranya dengan memikirkan pilihan komunikasi dengan menyapa secara langsung untuk kemudian menunggu respon dari pelanggan, memperkirakan bahwa ketika dirinya sudah menyapa pelanggan, selanjutnya dapat saling menyesuaikan cara berkomunikasi mereka, Selain itu pekerja salon tunarungu cenderung akan memikirkan terlebih dahulu kalimat verbal maupun non verbal, tindakan apa yang akan mereka tunjukkan kepada pelanggan baru. Hal ini tidak lain merupakan sebuah usaha di mana pekerja salon tunarungu ingin diterima dengan baik oleh pelanggan, melalui langkah-langkah atau proses yang memang sudah mereka pertimbangkan sebelum mereka bertemu atau berinteraksi.

Proses yang kedua yakni Proses retroaktif adalah suatu proses di saat seseorang menjelaskan perilaku orang lain ketika bertemu. Proses ini adalah proses yang berada dalam tahap pasca interaksi, di mana seseorang akan berusaha menjelaskan bagaimana interaksi tersebut berjalan serta perilaku dan pilihan membalas yang diterima serta dikirimkan kepada lawan bicara yang baru ditemui. Pekerja salon tunarungu menjelaskan bagaimana respon lawan bicara atau pelanggan baru, bagaimana mereka berperilaku setelah berkomunikasi dengan dirinya penyampaian informasi antara dirinya dengan pelanggan baru kadang dilakukan secara berulang dan kadang 
melibatkan orang ketiga yang lebih paham kondisi informan sehingga penyampaian informasi dapat berlangsung dengan baik. Terdapat penjelasan dari teori mengenai proses retroaktif yang ada pada pernyataan informan, di mana informan berada dalam proses ketika ia menggambarkan perilaku dan sikap yang dilakukan lawan bicaranya pasca berinteraksi dengannya. Setelah berkomunikasidengan pelanggan baru, para pekerja salon tunarungu memiliki gambaran apa yang harus dilakukan selanjutnya. Proses pengurangan ketidakpastian retroaktif ini merupakan bentuk analisis situasi yang dialami oleh informan di Salon Niniek. Proses ini juga menegaskan bahwa komunikasi interpersonal untuk mengurangi ketidakpastian memang dilakukan oleh pekerja salon tunarungu dan memiliki dampak yang berarti bagi kelangsungan atau keberlanjutan pekerjaan mereka dalam lingkungan sosial di kampung Turisari Mangkubumen.

Ada beberapa faktor penting dalam proses pengurangan ketidakpastian yang dilakukan oleh pekerja salon tunarungu seperti komunikasi verbal, ekspresi afiliasi non verbal, pencarian informasi, kedekatan (intimacy), timbal balik (reciprocity), kesamaan (similarity), kesukaan (liking) (West \& Turner, 2008).

1) Komunikasi Verbal, pada awal interaksi, penyampaian kata dan kalimat secara verbal merupakan sebuah proses yang juga membantu mengurangi ketidakpastian. Meskipun merasa kesulitan dalam pelafalan namun komunikasi secara verbal tetap digunakan oleh pekerja tuna rungu mengingat yang dihadapi adalah orang-orang yang memang terbiasa menggunakan komunikasi verbal, ketika seseorang membatasi diri dengan tidak banyak berbicara, maka lawan bicara akan semakin mengalami ketidakpastian, menurutnya lebih baik mereka mencoba untuk berkomunikasi dengan pelanggan meskipun harus dengan penyesuaian daripada tidak menggunakan komunikasi verbal sama sekali. Komunikasi verbal di harapkan mampu menunjukkan keterbukaan dan penerimaan dalam sebuah pembicaraan, khususnya ketika sedang melakukan tindakan dalam hal pekerjaan yang di mana seseorang akan merasa bahwa dirinya bisa masuk dan diterima ke dalam lingkungan sosial masyarakat (West \& Turner, 2008). Informan juga menunjukkan bahwa adanya percakapan yang lebih kerap terjadi akan membuka peluang pengumpulan informasi mengenai orang lain atau lawan bicaranya dan mengurangi ketidakpastian yang mereka alami.

2) Ekspresi afiliasi non-verbal. merupakan ekspresi berupa gesture atau gerak tubuh, kontak mata atau pun jarak yang muncul dalam sebuah interaksi komunikasi yang sedang berjalan. Ekspresi afiliasi non verbal ini menjadi faktor penting dalam pengurangan ketidakpastian karena semakin tinggi jumlah ekspresi non verbal yang muncul pada situasi awal berkomunikasi, maka dapat di pastikan bahwa ketidakpastian dalam interaksi awal tersebut mengalami penurunan atau dengan kata lain telah berkurang (West \& Turner, 2008).

Ketika pekerja salon tunarungu berkomunikasi dengan pelanggan baru, maka pelanggan yang baru dikenal akan cenderung membatasi ekspresi non verbalnya seperti memberikan jarak yang cukup jauh dalam berkomunikasi. Hal ini membuat pekerja salon tuna rungu merasa kesulitan karena mereka hanya dapat memahami komunikasi verbal apabila mendekatkan diri dengan lawan bicara, melihat gerak bibir mereka. Penggunaan komunikasi non verbal penting untuk dapat memahami pesan yang disampaikan, mengingat tidak semua orang memahami bahasa isyarat yang umum digunakan oleh kaum tunarungu. Mereka mengharapkan pelanggan baru juga menggunakan komunikasi non verbal agar pesan yang disampaikan dapat mereka terima. Beberapa informan menuturkan bahwa komunikasi awal dengan pelanggan membuatnya tidak nyaman karena jarak yang terlalu jauh, sebagaimana orang normal yang memiliki ketidakpastian akan merasa tidak nyaman dengan awal interaksi yang hanya memiliki sedikit ekspresi 
afiliasi non verbal. Dalam kasus tuna rungu afiliasi non verbal berperan sangat penting mengingat mereka memiliki keterbatasan dalam memahami komunikasi verbal. Untuk berkomunikasi dengan pelanggan normal, mereka menggunakan pengaturan jarak dengan mendekatkan diri ketika berbicara, pandangan mata yang fokus ke pelanggan, ekspresi ramah, hingga gerakan tangan untuk memudahkan penyampaian pesan. Orang-orang tunarungu secara kreatif menjalankan agensi dalam memanfaatkan berbagai cara untuk membuat diri mereka dipahami dengan mendengarkan orang, misalnya, gerakan ikonik, menuliskan katakata, menunjuk (Kusters, 2017).

Informan pada awalnya merasakan bahwa pelanggan baru menunjukkan ekspresi yang tidak terlalu bervariasi ketika awal interaksi dan tidak memberikan informasi mengenai jasa perawatannya, informan pun berusaha untuk mendekati dan menunjukkan ekspresi non verbal dengan lebih aktif. Dalam penelitian Anazuhriah juga menyatakan hal yang hampir sama, di mana ketika orang baru yang berbeda tempat, kampung, wilayah, ini tidak banyak berekspresi, maka pada awalnya mereka juga akan membatasi interaksi dan komunikasi yang akan mereka lakukan (Zuhriah, 2019).

3) Pencarian informasi. Pencarian informasi dalam pengurangan ketidakpastian adalah ketika seseorang merasa tingkatan ketidakpastiannya mengganggu, maka seseorang akan meningkatkan usaha pencarian informasi akan orang lain (West \& Turner, 2008).

Di saat pencarian informasi mulai tidak dilakukan lagi, maka tingkat ketidakpastian yang dialami juga mengalami penurunan. Pekerja salon tunarungu juga melalui hal ini ketika berada dalam masa-masa awal berada di salon dan tengah mengalami proses pengurangan ketidakpastian dalam pekerjaan, ia membutuhkan informasi akan treatment yang kerap dipilih pelanggan baru, di mana informasi tersebut harus dicari dan didapatkan untuk mengurangi ketidakpastian. Beberapa informan mencari informasi dengan bertanya kepada pemilik salon untuk mencari informasi mengenai kelengkapan treatment yang ada. Ketika seseorang sudah memiliki gambaran dan penjelasan mengenai apa yang akan atau sedang dihadapi, maka kebutuhan pencarian informasinya akan berkurang, hal ini berarti gambaran atau penjelasan serta informasi yang cukup akan membantu seseorang untuk mengurangi ketidakpastiannya (West \& Turner, 2008).

Beberapa informan tidak mencari informasi sebelum masuk ke salon melainkan mencari informasi dengan observasi sendiri ketika sudah ada di salon. Kegiatan pengumpulan informasi yang dilakukan informan tidak hanya dilakukan sekali saja, namun pencarian informasi ini adalah sebuah rangkaian proses yang pekerja salon tunarungu lakukan secara berkelanjutan ketika di dalam dirinya muncul ketidakpastian akan suatu hal yang berkaitan dengan pekerjaannya.

4) Kedekatan (intimacy). Dasar dari teori pengurangan ketidakpastian mengacu pada isi dari komunikasi yang terjadi. Isi komunikasi yang semakin dekat atau intim, akan membawa ketidakpastian pada level yang rendah. Hal ini merupakan faktor penting di dalam proses pengurangan ketidakpastian. Karena semakin dekat isi pembicaraan seseorang mampu menunjukkan bahwa tingkat ketidakpastian dalam diri seseorang akan orang lain berada pada level yang rendah. Seseorang yang tidak mengenal apalagi saling memahami, tidak akan mungkin memiliki keterbukaan hingga memiliki isi pembicaraan yang intim atau memiliki kedekatan. Salah seorang informan telah memiliki kedekatan dengan salah seorang pelanggan baru. Pembicaraan yang intensitasnya lebih banyak menunjukkan bahwa ada kedekatan isi pesan yang dimiliki antar pekerja salon tunarungu, sehingga ketidakpastian di dalam dirinya berkurang. Faktor intimasi ini merupakan faktor yang berada dalam proses di mana mereka sudah melakukan interaksi dan memiliki hubungan yang terus berlanjut. Proses ini menjadi penting karena dalam berkomunikasi, semakin terbuka dan 
dekatnya pembicaraan satu sama lainnya, akan membangun perasaan percaya serta mengurangi ketidakpastian akan diri seseorang (West \& Turner, 2008).

Semakin intim atau dekat isi dari pesan yang saling tersampaikan dalam interaksi komunikasi pekerja salon tunarungu, maka ketidakpastiaan dalam diri mereka juga semakin menurun. Perasaan nyaman muncul dalam diri mereka ketika intimasi terbentuk, terjalin kedekatan dalam membangun kepribadian dan perhatian khusus (Zuhriah, 2019)

5) Timbal balik (reciprocity). dalam teori pengurangan ketidakpastian memiliki makna bahwa semakin besar ketidakpastian yang dialami seseorang, maka timbal balik akan semakin besar dan banyak pula. Seseorang akan semakin banyak melakukan tanya jawab dalam sebuah interaksi ketika ia masih membutuhkan banyak informasi yang harus dikumpulkan untuk mengurangi ketidakpastian yang ada dalam dirinya (West \& Turner, 2008).

Beberapa informan menjelaskan pertanyaan yang mereka sampaikan variatif ketika mereka berada pada awal-awal berkomunikasi. Selanjutnya ketika informan mengalami pengurangan ketdakpastian, interaksi mereka berubah menjadi saling bertegur sapa dan interaksi ringan, bukan semata-mata kegiatan timbal balik untuk mengumpulkan informasi lagi. Kegiatan timbal balik yang setimpal juga akan menunjukkan bagaimana selanjutnya mereka akan berinteraksi. Intensitas pertanyaan yang saling dipaparkan dan diterima langsung oleh mereka lebih banyak juga bervariatif ketika mereka berada pada awal-awal berkomunikasi (Zuhriah, 2019).

6) Kesamaan (similarity) yang ada dalam proses pengurangan ketidakpastian merujuk pada pernyataan Charles Berger dan Richard Calabrese yang menyatakan bahwa ketika orang saling berinteraksi di dalamnya terdapat banyak kesamaan antar diri mereka, ketidakpastian pasti akan menurun. Kesamaan (similarity) menunjukkan bahwa seseorang yang memiliki pemikiran atau pun pendapat bahkan perilaku yang sejalan dengan kita adalah orang yang akan juga memahami banyak hal seperti apa yang kita pahami tanpa harus memikirkan dan menjelaskan penjelasan-penjelasan alternatif lain (West \& Turner, 2008).

Kesamaan yang banyak akan pelanggan baru dengan pekerja salon membuat interaksi dan hubungan yang mereka lakukan terasa lebih nyaman. Kesamaan mngenai selera, dimana mereka menyukai merek produk perawatan yang sama. Oleh karena itu, tidak heran bahwa pekerja salon tunarungu di Salon Niniek yang memiliki kedekatan atau bersahabat baik cenderung memiliki kesamaan (similarity) dalam hal-hal tertentu

7) Kesukaan (liking). dalam proses pengurangan ketidakpastian mengarah pada tinggi rendahnya ketidakpastian akan diri seseorang akan mempengaruhi tingkat kesukaan kita terhadap orang tersebut. Semakin besarketidakpastian, maka semakin rendah kesukaan kita terhadap orang tersebut. Sebaliknya, di saat ketidakpastian minim, maka kita akan memiliki kesukaan yang besar akan orang lain. Kesamaan dan kesukaan memiliki hubungan yang positif dalam proses pengurangan ketidakpastian, kecenderungan yang seseorang cari dari sebuah interaksi adalah kesamaan dengan orang lain di mana hal ini cenderung harus menghasilkan kesukaan (West \& Turner, 2008).

Hasil wawancara terhadap informan menunjukkan hal-hal yang memicu kesukaan pada pelanggan baru diantaranya sikap ramah, sopan santun, sikap mereka yang mau berinteraksi selama treatment, berbicara dengan halus dan bersedia membayar sebagaimana harga yang ditetapkan. Pekerja salon tunarungu di Salon Niniek dalam melakukan interaksi berharap bahwa mereka akan memiliki kesan dan penilaian yang baik agar dapat melanjutkan interaksi dan membangun hubungan yang lebih intensif dan dekat. Ketika mereka mengalami suatu permasalahan yang menimbulkan ketidaksukaan mereka akan cenderung menutup diri. 
Adapun strategi informan dalam mengurangi ketidakpastian, diantaranya Strategi pasif merupakan strategi yang dilakukan untuk mengurangi ketidakpastian dengan seseorang sebelum berinteraksi dengan orang lain yang sekiranya memiliki informasi (Febriani dan lqbal, 2015). Peneliti sendiri menemui bahwa yang mereka pakai adalah strategi pasif yakni strategi di mana pekerja salon tunarungu ini tidak secara aktif melainkan secara pasif mencari informasi yang hanya mengamati orang-orang yang ingin ia ketahui lebih dalam. Hal ini sejalan dengan yang ditulis oleh Herovic dalam bukunya bahwa, tidak dapat di duga bahwa seseorang termasuk para karyawan akan melakukan kegiatan pengumpulan informasi untuk mengurangi ketidakpastiannya (Herovic et.al, 2018). Pekerja salon tunarungu ini melakukan strategi pasif yang terlihat melalui pengamatan sebagai upaya mencari tahu mengenai pelanggan baru dan apa yang harus mereka lakukan. Hal ini sejalan dengan penelitian yang dilakukan oleh Febriani dan lqbal bahwa melakukan pengamatan terhadap sistem kerja dan karakter dapat dilakukan untuk mengurangi ketidakpastian yang mereka alami (Febriani dan lqbal, 2015).

Jenis strategi lain yang peneliti temukan adalah strategi aktif. Strategi aktif merupakan strategi yang melibatkan usaha aktif untuk mengetahui orang yang ingin diketahui informasinya, namun tanpa harus berjumpa atau menghadapi orang tersebut secara langsung (Antheunis et al., 2012).

Sama halnya dengan strategi pasif, strategi ini ada dalam kondisi pekerja salon tunarungu belum melakukan interaksi secara langsung dengan pelanggan baru. Strategi ini mengarah kepada bagaimana seseorang mampu mencari dan mengumpulkan informasi dengan langkah yang setingkat lebih tinggi dari strategi pasif, meskipun sama-sama tidak memiliki kontak atau interaksi secara langsung dengan orang yang ingin diketahui informasinya. Strategi aktifjuga digunakan oleh salah satu informan yang merupakan pekerja salon tunarungu yang ada di Salon Niniek di mana pekerja salon tunarungu ini mencari informasi dengan menggunakan bantuan orang ketiga atau dengan kata lain menanyakan mengenai seseorang melalui orang lain. Strategi ini memungkinkan pekerja salon tunarungu melakukan riset atau pencarian informasi tanpa ia harus mengambil risiko malu atau pun ragu seperti ketika seseorang berjumpa langsung dan berbicara dengan orang asing atau orang yang belum ia kenal. Strategi aktif memang digunakan oleh informan yakni dengan menggunakan bantuan pihak ketiga untuk mencari tahu informasi mengenai pelanggan baru.

Strategi interaktif juga digunakan oleh pekerja salon di Turisari Mangkubumen di mana strategi ini dilakukan dengan berinteraksi secara langsung dengan pelanggan baru. Strategi ini menerapkan usaha yang melibatkan akuisisi atau perolehan informasi melalui interaksi langsung berupa sapaan, berkenalan kemudian bertanya kepada target atau sasaran yaitu orang asing atau pelanggan baruyang baru ia temui. Strategi ini dianggap lebih nyaman dilakukan oleh pekerja salon tunarungu di Turisari Mangkubumen karena membuat mereka lebih mudah diterima dalam situasi sosial dan lingkungan sosial mereka. Kehadiran diri secara nyata dan langsung membuat pekerja salon tunarungu mampu merasa bahwa seseorang akan lebih cepat memahami satu sama lain. Strategi interaktif terjadi ketika pengamat dan orang yang diamati terlibat dalam kontak secara langsung atau berinteraksi dengan tatap muka maksudnya, pembicaraan yang mungkin melibatkan pembukaan diri, mempertanyakan secara langsung, dan taktik pencarian informasi yang lain (West \& Turner, 2008)

\section{F. KESIMPULAN}

Bentuk ketidakpastian yang dialami pekerja salon tunarungu saat menghadapi pelanggan baru diantaranya ketidakpastian kognitif dan ketidakpatian perilaku. Ketidakpastian kognitif umumnya berupa kekhawatiran akan keterbatasan yang mereka memiliki membuat mereka kesulitan untuk mendapatkan informasi yang jelas, 
tidak mampu memahami keinginan pelanggan, ketakutan akan prasangka buruk dari pelanggan. Adapun ketidakpastian perilaku berupa ketidakmampuan dalam memperkirakan perilaku pelanggan baru, khawatir aka nada keluhan apabila tidak puas dengan perawatan yang diberikan, kekhawatiran tentang adanya pelanggan yang menawar harga lebih rendah dari yang sudah ditentukan.

Adapun proses pengurangan ketidakpastian yang dialami pekerja salon tunarungu yakni proses proaktif dan retroaktif. Dalam proses proaktif pekerja salon tunarungu memikirkan pilihan komunikasi yang akan dilakukan, diantaranya meyapa secara langsung, memikirkan komunikasi verbal maupun non verbal serta tindakan apa yang akan mereka lakukan saat bertemu pelanggan baru. Adapun proses retroaktif dimana pekerja tunarungu menjelaskan bagaimana interaksi dengan pelanggan baru, bagaimana sikap dan perilaku lawan bicara pasa berinteraksi dengan dengan mereka. Selain itu ada faktor penting dalam proses pengurangan ketidakpastian diantaranya: 1) Komunikasi verbal, pekerja salon tunarungu pada masa awal interaksi menggunakan komunikasi verbal meskipun kesulitan dalam pelafalan dan membutuhkan penyesuaian. 2) Ekspresi afiliasi non verbal, pekerja salon tunarungu menggunakan isyarat-isyarat non verbal berupa pengaturan jarak dengan mendekatkan diri pada lawan bicara, pandangan mata yang fokus ke lawan bicara, ekspresi ramah serta gerakan tangan untuk memudahkan penyampaian pesan. 3) Pencarian informasi, hal ini terkait dengan informasi entang treatment yang sering dipilih pelanggan baru dengan bertanya kepada pemilik salon atau dengan melakukan observasi. 4) Kedekatan (intimacy), salah satu pekerja salon memiliki kedekatan dengan pelanggan baru, sehingga perasaan nyaman muncul dan tejalin kedekatan diantara mereka. 5) timbal balik (reciprocity), pekerja salon tunarungu melakukan interaksi yang sifatnya tanyajawab. Pertanyaan yang mereka sampaikan variatif ketika mereka berada pada awalawal berkomunikasi. Selanjutnya ketika informan mengalami pengurangan ketdakpastian, interaksi mereka berubah menjadi saling bertegur sapa dan interaksi ringan, bukan semata-mata kegiatan timbal balik untuk mengumpulkan informasi lagi. 6) Kesamaan (similarity), Beberapa pekerja salon tunarungu memiliki kesamaan dengan pelanggan baru terkait selera, dimana mereka menyukai merek produk perawatan yang sama, selain itu hal lainnya seperti karakter, hobi yang membuat mereka merasa lebih dekat. 7) Kesukaan (Liking), adapun hal-hal yang memicu kesukaan pada pelanggan baru diantaranya sikap ramah, sopan santun, sikap mereka yang mau berinteraksi selama treatment, berbicara dengan halus dan bersedia membayar sebagaimana harga yang ditetapkan.

Strategi pengurangan ketidakpastian yang dilakukan oleh pekerja salon tunarungu yakni: 1) Strategi pasif, dengan melakukan pengamatan sebagai upaya mencari tahu mengenai pelanggan baru dan apa yang harus mereka lakukan. 2) Strategi aktif, pekerja salon tunarungu mencari informasi dengan menggunakan bantuan orang ketiga atau dengan kata lain menanyakan mengenai seseorang melalui orang lain. 3) Strategi interaktif, yakni pekerja salon tunarungu melakukan interaksi secara langsung untuk mengurangi rasa ketidakpastian yang mereka alami.

Peneliti menyadari bahwa penelitian ini masih jauh dari sempurna, semoga penelitian ini dapat menjadi acuan bagi penelitian-penelitian berikutnya. Semoga untuk penelitian selanjutnya dapat menggunakan metode penelitian yang lebih bervariasi hingga ke ranah yang lebih luas dan mendalam. 


\section{REFERENSI}

Antheunis, M. L., Schouten, A. P., Valkenburg, P. M., \& Peter, J. (2012). Interactive Uncertainty Reduction Strategies and Verbal Affection in Computer-Mediated Communication. Communication Research. https://doi.org/10.1177/0093650211410420

Berger, C. R, C. (1975). Some Explorations in Initial Interaction And Beyond: Toward a Developmental Theory of Interpersonal Communication. Human Communication Research. 1(2), 99-112.

Febriani N. W., I. (2015). Jurnal Komunikasi Profetik. Strategi Pengurangan Ketidakpastian dalam Komunikasi Interpersonal (Studi Fenomenologi pada Peserta On The Job Training Program Ke Jepang PT Hitachi Construction Machinery Indonesia Periode Pemberangkatan 2009-2012), 08(2), 66-69.

Gibbs, J.L., Ellison, N.B. \& Lai, C.H. (2011). First Comes Love, Then Comes Google: An Investigation of Uncertainty Reduction Strategies and Self-Disclosure in Online Dating. Communication Research. 38(1), 70-100.

Haenudin. (2013). Pendidikan Anak Berkebutuhan Khusus Tunarungu. Jakarta: Luxima.

Krisyantono, R. (2006). Teknik Praktis Riset Komunikasi. Jakarta: Kencana Prenada Media Group.

Kusters, A. (2017). Gesture-based customer interactions: deaf and hearing Mumbaikars' multimodal and metrolingual practices. International Journal of Multilingualism. https://doi.org/10.1080/14790718.2017.1315811

Miles, M. B., Huberman, A. M., \& Saldana, J. (2014). Cross-case data analysis. In Qualitative data analysis: An expanded sourcebook.

Morrisan. (2018). Teori Komunikasi: Individu Hingga Massa. Jakarta: Prenada Media Group.

Mulyana, D. (2010). Ilmu Komunikasi: Suatu Pengantar. Bandung: PT. Remaja Rosdakarya.

Primasari, W. (2014). Pengelolaan Kecemasan dan Ketidakpastian Diri Dalam Berkomunikasi Studi Kasus Mahasiswa Perantau UNISMA Bekasi. Jurnal Ilmu Komunikasi.

Sugiyono. (2017). Metode Penelitian Kuantitatif, Kualitatif, dan R \& D. Bandung: Penerbit Alfabeta.

Susilo, A. P. (2017). MEMAHAMI KOMUNIKASI PENYESUAIAN DIRI ANAK TUNARUNGU DI SEKOLAH INKLUSI. Interaksi: Jurnal Ilmu Komunikasi. https://doi.org/10.14710/ interaksi.6.2.1-10

West, R., \& Turner, L. H. (2008). Introducing Communication Theory. In Introducing Communication Theory Analysis Application.

Wijaya, Immanuel Khomala. (2017). Proses Komunikasi Interpersonal Bawahan Tuna RunguWicara Dengan Atasannya (Supervisor) Di Gunawangsa Hotel Manyar Surabaya. Jurnal E-Komunikasi. Vol. 5(1), 1-12

Young, Alys, et al. (2017). Hearing people perceiving deaf people through sign language interpreters at work: on the loss of self through interpreted communication. Journal of Applied Communication Research. Vol. 47(1), 90-110.

Zuhriah, A. (2019). Pengurangan Ketidakpastian Melalui Komunikasi Interpersonal Remaja Panti Asuhan (Studi Pada Remaja Ppsa "Woro Wiloso" Salatiga). Jurnal Common. https://doi.org/10.34010/common.v3i1.1624 